ANUVA Volume 2 (2): 145-152, 2018

Copyright (02018, ISSN: 2598-3040 online

Available Online at: http://ejournal.undip.ac.id/index.php/anuva

\title{
Membangun Kepercayaan Diri Pustakawan sebagai Upaya Aktualisasi Diri dalam Masyarakat
}

\author{
Roro Isyawati Permata Ganggi ${ }^{*}$ ) \\ ${ }^{I}$ Program Studi Ilmu Perpustakaan, Fakultas Ilmu Budaya, Universitas Diponegoro, \\ Jl. Prof. Soedarto, SH, Kampus Undip Tembalang, Semarang, Indonesia \\ *) Korespondensi: isya.ganggi@gmail.com
}

\begin{abstract}
[Title: Build the Librarian's Confidence as Self-Actualization in Society ] Librarian is one profession that is very near to the knowledge, unfortunately this profession is underestimated by society. Librarian is only considered the professions which keep warehouse of book rather than as "keeper" of the knowledge. The bad perception to the librarian has an impact for librarian's confidence to their profession. The lack of trust of librarian is influenced by several factors such as: self concept, gender, culture, level of education, socioeconomic status; and experience. The increase of librarian's self-confidence of librarians can be done by some efforts, namely: identifying the cause of low confidence and self-competency domains that are important, emotional support and social acceptance, achievement, and problem solving (coping). Selfconfidence is one of the efforts to complete the needofr self-esteem for the librarian profession. The need for self-esteem to the profession of librarian will be able to bring the profession of librarian toward the next stage, the need for self-actualization. Self-actualization to the librarian will be able to give a positive impact asgainst that profession. Positive impacts of self-actualization fulfillment became reinforce for the profession hierarchy and also change the image of librarian to be better image in the society.
\end{abstract}

Keywords: librarians confidence; self-actualization of librarians; hierarchy of needs

\begin{abstract}
Abstrak
Pustakawan merupakan salah satu profesi yang sangat dekat dengan ilmu pengetahuan, sayangnya profesi ini masih dipandang sebelah mata oleh masyarakat. Pustakawan hanya dianggap sebagai profesi penjaga gudang buku bukan sebagai penjaga ilmu pengetahuan. Citra yang kurang baik ini tentu berdampak pada kepercayaan diri pustakawan terhadap profesinya. Kurangnya kepercayaan pustakawan dipengaruhi oleh beberapa faktor yaitu: konsep diri; jenis kelamin; budaya; tingkat pendidikan; status sosial ekonomi; dan pengalaman. Penguatan kepercayaan diri pustakawan dapat dilakukan dengan beberapa usaha, yaitu: mengidentifikasi penyebab rendahnya rasa percaya diri dan domain-domain kompetensi diri yang penting; dukungan emosional dan penerimaan sosial; prestasi; mengatasi masalah (coping). Kepercayaan diri merupakan salah satu upaya untuk melengkapi kebutuhan akan penghargaan terhadap profesi pustakawan. Kebutuhan akan penghargaan terhadap profesi pustakawan yang terpenuhi akan mampu membawa profesi pustakawan untuk memenuhi tahapan selanjutnya, yaitu kebutuhan akan aktualisasi diri. Aktualisasi diri terhadap profesi pustakawan akan mampu memberikan dampak positif terhadap profesi pustakawan. Dampak positif yang terciptadari penemuhan aktualisasi diri menjadi penguatan bagi hirarki kebutuhan profesi pustakawan dan juga merubah citra pustakawan yang lebih baik di masyarakat.
\end{abstract}

Kata kunci: kepercayaan diri pustakawan; aktualisasi diri pustakawan; hirarki kebutuhan

\section{Pendahuluan}

Jargon "pahlawan tanpa tanda jasa" yang disematkan untuk profesi guru tentu membuat profesi guru mendapatkan tempat tersendiri di masyarakat karena jasanya mencerdaskan masyarakat. Ketika berbicara tentang guru tentu tidak akan lepas dari membicarakan mengenai ilmu dan buku, padahal bukan 
hanya guru saja yang identik dengan dua kata tersebut. Pustakawan juga merupakan profesi yang dekat sekali dengan buku dan ilmu, profesi yang juga dapat mencerdaskan masyarakat, tetapi mengapa ketika profesi guru menjadi primadona di masyarakat profesi pustakawan justru terdengar datar-datar saja?

Berdasarkan pemberitaan melalui situs kompas.com (Wulan, 2010) menyatakan bahwa selama ini pustakawan cenderung minder dengan profesi sebagai pustakawan. Selain tidak diminati, mayoritas masyarakat juga belum mengenal tugas dan peran penting dari kehadiran seorang pustakawan. Berdasarkan berita tersebut pustakawan cenderung minder (kurang percaya diri) terhadap profesinya. Adanya rasa minder tersebut membuat pustakawan kurang dapat mengapresiasikan diri dalam upaya pengembangan profesinya sebagai upaya aktualisasi diri di masyarakat. Lalu apa usaha apa yang dapat dilakukan pustakawan untuk meningkatkan kepercayaan dirinya?

\section{Metode Penelitian}

Penelitian ini menggunakan metode penelitian kualitatif. Pengumpulan data dalam penelitian ini dilakukan dengan cara studi dokumentasi dari sumber online maupun tercetak. Data yang terkumpul kemudian diolah untuk mengetahui bagaimana membangun kepercayaan diri pustakawan sebagai upaya aktualisasi diri dalam masyarakat.

\section{Analisis dan Pembahasan}

\subsection{Kepercayaan Diri}

Branden dalam Walgito (2002: 7) mengatakan bahwa kepercayaan diri adalah kepercayaan seseorang pada kemampuan yang ada dalam dirinya. Individu yang mempunyai kepercayaan diri dalam melakukan sesuatu kegiatan tanpa bertanya kepada orang lain apakah yang dikerjakan itu perlu atau tidak, benar atau tidak, ia akan melakukan kegiatan itu. Jika seseorang mempunyai keyakinan bahwa apa yang akan dikerjakan itu benar sesuai dengan yang ada dalam dirinya, maka hal tersebut akan dikerjakan tanpa meminta pertimbangan dari pihak lain. Pendapat Angelis (2003: 10) bahwa kepercayaan diri merupakan keyakinan dalam jiwa individu dalam menghadapi segala tantangan hidup. Jika seseorang merasa yakin pada dirinya sendiri, maka apa pun tantangan hidup ini akan dihadapinya.

Jadi, kepercayaan diri adalah suatu keyakinan yang dimiliki individu untuk mengembangkan penilaian positif terhadap diri sendiri maupun terhadap lingkungan atau situasi yang dihadapi. Selain itu, dapat menerima segala kelebihan dan kekurangan yang dimiliki sehingga dapat mengaktualisasikan diri terhadap lingkungan yang dihadapinya, yang meliputi percaya pada kemampuan diri sendiri, bertindak mandiri dalam mengambil keputusan, memiliki konsep diri yang positif dan berani mengungkapkan pendapat. 


\subsection{Karakteristik Pustakawan yang Percaya Diri}

Menurut Frenson dalam Susanti (2008: 26) ada beberapa karakteristik/ciri dari rasa percaya diri tinggi yaitu: menerima dan menghargai dirinya sendiri maupun orang lain, optimis dan memiliki keyakinan akan dirinya dan kemampuan yang ia miliki, tidak takut dan berani mencoba melakukan halhal dalam situasi apapun, sportif berani bertanggung jawab dan mau menerima kekurangan dan kegagalan yang dimilikinya, dengan dirinya dengan lingkungan dan terakhir adalah mandiri yang berarti tidak selalu bergantung pada orang lain dan tidak perlu membandingkan dirinya dengan orang lain.

Sedangkan menurut teori lainnya, yaitu menurut Lauster (1997), ciri-ciri orang yang mempunyai kepercayaan diri adalah sebagai berikut:

a. Percaya pada kemampuan sendiri

Suatu keyakinan atas diri sendiri terhadap segala fenomena yang terjadi, yang berhubungan dengan kemampuan individu untuk mengevaluasi serta mengatasi fenomena yang terjadi. Kepercayaan atau keyakinan pada kemampuan yang ada pada diri seseorang adalah salah satu sifat orang yang percaya diri. Apabila orang yang percaya diri telah meyakini kemampuan dirinya dan sanggup untuk mengembangkannya, rasa percaya diri akan timbul bila seseorang melakukan kegiatan yang bisa dia lakukan. Artinya keyakinan dan rasa percaya diri itu timbul pada saat seseorang mengerjakan sesuatu dengan kemampuan yang ada pada dirinya.

Pustakawan perlu percaya pada kemampuan diri sendiri dalam melakukan rutinitas kerjanya. Pustakawan yang memiliki rasa percaya pada kemampuan diri sendiri akan lebih mudah berkembang, terutama dalam menghadapi perubahan teknologi yang begitu pesat yang pastinya akan berdampak juga pada rutinitas kerja di perpustakaan.

b. Memiliki rasa positif terhadap diri sendiri

Adanya penilaian yang baik dari dalam diri sendiri, baik dari pandangan maupun tindakan yang dilakukan yang menimbulkan rasa positif terhadap diri sendiri. Sikap menerima diri apa adanya itu, akhirnya dapat tumbuh berkembang sehingga orang percaya diri dan dapat menghargai orang lain dengan segala kekurangan dan kelebihannya. Seseorang yang memiliki kepercayaan diri, jika mendapat kegagalan biasanya mereka tetap dapat meninjau kembali sisi positif dari kegagalan itu. Setiap orang pasti pernah mengalami kegagalan baik kebutuhan, harapan dan cita-cita. Untuk menyikapi kegagalan dengan bijak diperlukan sebuah keteguhan hati dan semangat untuk bersikap positif.

Pustakawan harus menanamkan rasa positif terhadap diri sendiri. Hal ini menjadi tantangan tersendiri karena selama ini pustakawan kurang mampu melihat citra positif pada profesi yang ia tekuni. Seorang pustakawan harus mampu melihat sisi positif dari profesinya yang sehingga akan muncul rasa bangga dan cinta terhadap profesinya.

c. Berani mengungkapkan pendapat 
Adanya suatu sikap untuk mampu mengutarakan sesuatu dalam diri, yang ingin diungkapkan kepada orang lain tanpa adanya paksaan atau rasa yang dapat menghambat pegungkapan tersebut. Individu dapat berbicara di depan umum tanpa adanya rasa takut, berbicara dengan memakai nalar dan secara fasih, dapat berbincang-bincang dengan orang dari segala usia dan segala jenis latar belakang. Serta menyatakan kebutuhan secara langsung, terbuka, berani mengeluh jika merasa tidak nyaman dan dapat berkampanye didepan orang banyak.

Selama ini pustakawan dianggap sebagai kaum minoritas sehingga sering kali pendapat dari pustakawan terabaikan. Terkadang beberapa pustakawan sedikit kesulitan dalam mengungkapkan pendapatnya. Kedua hal tersebut tentunya sangat berdampak terhadap kepercayaan diri pustakawan terutama dalam mengungkapkan pendapat. Mengungkapkan pendapat bukan hanya secara lisan dalam suatu forum tetapi juga secara tertulis melalui suatu media. Usaha yang dapat dilakukan supaya pustakawan berani untuk mengungkapkan pendapatnya adalah dengan memberikan pelatihan public speaking serta pelatihan menulis.

\subsection{Meningkatkan Kepercayaan Diri Pustakawan}

Pada kenyataan di lapangan masih banyak pustakawan yang kurang percaya diri terhadap dirinya dan terhadap profesinya, penyebab seorang pustakawan urang percaya atau minder, antara lain karena:

a. Konsep Diri

Pada faktor ini dalam pengamatan penulis, pustakawan belum memiliki konsep diri yang jelas. Disatu sisi pustakawan ingin dianggap sebagai penyedia layanan informasi, tetapi disisi lain pustakawan belum mampu memenuhi kebutuhan pemustakanya dengan baik. Hal ini dikarenakan perubahan teknologi pencarian informasi dan juga kebutuhan akan informasi saat ini sudah sangat berkembang. Selain itu pustakawan belum memiliki kreatifitas untuk memunculkan konsep diri pustakawan sebagai profesi yang menyenangkan di tengah-tengah masyarakat.

Bukan rahasia umum lagi jika citra diri pustakawan di masyarakat adalah seorang wanita yang judes, dengan sanggul dan sepatu pantofel, dan dia akan siap untuk berkata "sshh" bila ada keributan sekecil apapun. Citra diri pustakawan yang seperti ini tentunya akan membuat kepercayaan diri seseorang untuk terjun dalam profesi ini menjadi berkurang. Citra diri profesi pustakawan yang kurang baik dimata masyarakat tentu saja membawa pengaruh besar seorang pustakawan memandang profesinya sendiri.

b. Jenis Kelamin

Garrison dalam Rubin (2007: 386) berpendapat bahwa feminisasi keperpustakaan publik telah menciptakan pandangan yang rendah terhadap profesi ini, yang mana pandangan ini mendominasi pola-pikir para pria terdidik, seperti yang terjadi pada beberapa dekade yang lalu. Dengan kata lain, bidang pekerjaan yang berpotensi besar ini sering dipandang rendah statusnya, karena identik dengan 
ranah/bidang pekerjaan wanita. Adanya stereotype gender didalam perpustakaan membuat pustakawan laki-laki kurang percaya diri terhadap profesinya. Hal ini dapat terlihat dari bangku perkuliahan, dimana pada program studi ilmu perpustakaan hamper selalu didominasi oleh mahasiswa berjenis kelamin wanita.

d. Budaya

Budaya menonton yang lebih diminati dibandingkan membaca juga berdampak pada kepercayaan diri pustakawan. Dilihat lebih jauh budaya tidak suka membaca juga dialami oleh pustakawan, walaupun ia sebenarnya ada dalam "lading" ilmu dan informasi, masih banyak pustakawan yang tidak memanfaatkannya. Hal ini tentu saja membuat dunia kepustakawanan mengalami stagnansi karena pustakawannya tidak meng-upgrade pengetahuannya. Sehingga sangat disayangkan jika pustakawan yang dianggap sebagai penjaga dari ilmu pengetahuan belum memanfaatkan apa yang ia miliki.

e. Tingkat Pendidikan

Untuk menjadi seorang pustakawan dapat ditempuh dengan dua jalur yaitu, dengan pendidikan formal (mengikuti program pendidikan perguruan tinggi) atau nonformal (mengikuti pelatihan kepustakawanan). Dua jalur yang ada tersebut sebenarnya merupakan alternatif bagi seseorang agar dapat menjadi pustakawan. Tetapi hal tersebut justru menjadi pedang bermata dua, pustakawan yang mengikuti pendidikan formal membutuhkan waktu antara 3,5-4 tahun untuk menyelesaikan gelar kesarjanaannya, sedangkan yang mengikuti jalur nonformal hanya membutuhkan waktu kurang dari 4 bulan. Hal ini tentu memiliki dampak juga pada pustakawan yang lahir dari jenjang pendidikan nonformal cenderung lebih merasa minder dibandingkan dengan pustakawan yang lahir dari jenjang pendidikan formal.

\section{f. Status Sosial Ekonomi}

Dalam uraian diatas status sosial mempengaruhi tingkat kepercayaan diri seseorang. Masih sering kita temui ada stereotype masyarakat yang secara jelas menghakimi suatu jenis ilmu. Mahasiswa yang menuntut ilmu dalam bidang kesehatan dan hukum oleh masyarakat diidentikan sebagai jenis ilmu yang pelajarnya berasal dari kelas atas. Lalu bagaimana dengan perpustakaan? masyarakat masih memandang sebelah mata pada jenis keilmuan ini. Akhirnya mahasiswa didalam keilmuan ini pun cenderung tidak percaya diri.

g. Pengalaman

Kepercayaan diri diperoleh dari pengalaman yang mengecewakan adalah paling sering menjadi sumber timbulnya rasa rendah diri. Perpustakaan sering dikaitkan sebagai tempat pembuangan ketika ada pejabat yang melakukan kesalahan atau menunggu masa pensiun. Hal ini tentu saja membuat citra pustakawan makin rendah. 
Dari analisis faktor kepercayaan diri pustakawan. Maka untuk meningkatkan rasa percaya diri ada empat cara untuk meningkatkan rasa percaya diri pustakawan yaitu:

1. Mengidentifikasikan penyebab rendahnya rasa percaya diri dan domain-domain kompetensi diri yang penting.

Untuk meningkatkan rasa percaya diri pustakawan yang harus diperhatikan yaitu penyebab dari rendahnya rasa percaya diri. Kemudian mengidentifikasi hal-hal apa saja yang menjadi bagian dari kelemahan dan kelebihan tersebut. Seseorang memiliki tingkat rasa percaya diri yang paling tinggi ketika mereka berhasil di dalam domain-domain diri yang penting.

2. Dukungan emosional dan penerimaan sosial

Dukungan emosional dan persetujuan sosial dari orang lain merupakan pengaruh yang penting bagi rasa percaya. Sumber dukungan alternatif dapat dimunculkan secara informal seperti dukungan dari orang yang berpengalaman atau orang yang berpengaruh. Sedangkan secara formal melalui beberapa program. Dukungan orang masyarakat dan teman sejawat menjadi faktor yang berpengaruh terhadap rasa percaya diri pustakawan. Salah satu penelitian menunjukkan bahwa dukungan masyarakat dan teman sejawat sama-sama berhubungan dengan harga diri pustakawan secara keseluruhan.

3. Prestasi

Rasa percaya diri pustakawan meningkat lebih tinggi karena mereka tahu tugas-tugas apa yang penting untuk mencapai tujuan dan karena mereka telah melakukan tugas-tugas tersebut. Pentingnya sebuah prestasi dalam meningkatkan rasa percaya diri pustakawan memiliki kesamaan dengan konsep teori belajar sosial kognitif mengenai kualitas diri (self-efficacy) yang merupakan keyakinan individu bahwa dirinya dapat menguasai suatu situasi dan menghasilkan sesuatu yang positif.

4. Mengatasi masalah (coping)

Rasa percaya diri juga dapat meningkat ketika pustakawan menghadapi masalah dan berusaha untuk mengatasinya, bukan menghindarinya. Ketika pustakawan memilih mengatasi masalahnya dan bukan menghindarinya, pustakawan menjadi lebih mampu menghadapi masalah secara nyata, jujur, dan tidak menjauhinya. Perilaku ini menghasilkan suatu evaluasi diri yang menyenangkan yang dapat mendorong terjadinya persetujuan terhadap diri sendiri yang bisa meningkatkan rasa percaya diri dan perilaku yang sebaliknya dapat menyebabkan rendahnya rasa percaya diri.

\subsection{Kepercayaan Diri Pustakawan sebagai Upaya Aktualisasi Diri dalam Masyarakat}

Aktualisasi diri merupakan puncak piramida dari Hirarki Kebutuhan Abraham Maslow. Sebagai puncak dari piramida, maka aktualisasi diri dapat tercapai bila empat tahapan sebelumnya telah terpenuhi, yaitu: kebutuhana fisiologis, kebutuhan akan rasa aman, kebutuhan sosial dan kasih sayang, kebutuhan akan penghargaan. Kebutuhan fisiologis merupakan kebutuhan dasar manusia yang berupa sandang, papan, dan pangan. Kebutuhan akan rasa aman adalah kebutuhan seseorang untuk bebas dari rasa takut, ancaman dan tekanan. Kebutuhan sosial dan kasih sayang merupakan kebutuhan sesorang untuk dapat berinteraksi dengan orang lain dan merasakan serta memberikan kasih sayang kepada uang lain juga. 
Kebutuhan akan penghargaan meliputi kebutuhan untuk diakui oleh pihak lain, mendapat penghormatan dan harga diri. Setelah keempat kebutuhan tersebut terpenuhi barulah seseorang dapat memnuhi kebutuhan aktualisasi diri. Kebutuhan aktualisasi diri merupakan kemampuan untuk memaksimalkan potensi dan kemampuan diri sendiri.

Sebagai sebuah profesi tentunya kebutuhan fisiologis pustakawan sudah dapat terpenuhi. Pustakawan pun cenderung menjadi profesi yang aman dan jauh dari konflik yang membuat pustakawan tidak nyaman dan mengancam keselamatan pustakawan, sehingga kebutuhan akan rasa aman juga telah terpenuhi dlama profesi pustakawan. Profesi pustakawan merupakan profesi yang bersinggungan langsung dengan user perpustakaan sehingga kebutuhan akan interaksi sosial tentu mampu terpenuhi dengan baik. Kebutuhan akan penghargaan merupakan kebutuhan yang perlu ditingkatkan sebagai upaya untuk meraih puncak hirarki kebutuhan. Supaya profesi pustakawan mampu dihargai oleh orang lain sebagai suatu profesi yang bergengsi, pustakawan itu sendiri perlu yakin dan percaya diri terhadap profesinya. Kepercayaan diri pustakawan terhadap profesinya menentukan bagaimana cara pandang pustakawan tersebut dalam melihat profesinya. Pustakawan yang percaya diri dapat mengambil nilai-nilai positif dari rutinitas kerja yang dia lakukan, kemudian diharapkan pustakawan tersebut mampu menyebarkan nilai-nilai positif tersebut untuk pihak lain, sehingga terciptalah penghargaan publik terhadap profesi pustakawan.

Pemenuhan kebutuhan akan penghargaan terhadap profesi pustakawan mampu dilakukan salah satunya adalah dengan menanamkan rasa percaya diri pustakawan terhadap profesinya. Setelah kebutuhan akan penghargaan terhadap profesi dapat terpenuhi barulah pustakawan mampu dan dapat menjalankan kebutuhan akan aktualisasi diri. Aktualisasi diri membuat seorang pustakawan mampu memberikan kemampuan yang maksimal untuk pengembangan profesi dan karirnya. Hal ini secara tidak langsung akan memperkuat kebutuhan-kebutuhan yang ada dibawahnya. Aktualisasi diri pustakawan diharapkan mampu merubah image pustakawan yang ada selama ini dan menjadikan pustakawan sebagai profesi yang membanggakan dan dekat dengan masyarakat.

\section{Simpulan}

Pustakawan belum dapat mengaktualisasikan diri di masyarakat salah satunya karena tingkat kepercayaan dirinya yang masih rendah. Beberapa faktor yang membuat pustakawan kurang percaya diri terhadap profesinya, yaitu: konsep diri; jenis kelamin; budaya; tingkat pendidikan; status sosial ekonomi; pengalaman. Kurangnya kepercayaan diri pada pustakawan pada memberikan dampak pada belum tercapainya kebutuhan penghargaan terhadap profesi pustakawan, yang berakibat kebutuhan akan aktualisasi diri belum dapat sepenuhnya terpenuhi. Aktualisasi diri pustakawan perlu dilakukan agar pustakawan mampu memberikan hasil yang terbaik dari setelah mengerahkan kemampuan terbaik yang ia miliki. Aktualisasi diri juga merupakan salah satu cara supaya masyarakat lebih mengenal profesi pustakawan. Pustakawan yang percaya diri akan dengan mudah meleburkan diri dalam masyarakat dan bangga terhadap profesinya. 


\section{Daftar Pustaka}

Al-Ghifari, Abu. 2003. "Percaya Diri Sepanjang Hari, Panduan Sukses Generasi Qurani”. Bandung: Mujahidin.

Angelis, Barbara.2003. "Percaya Diri”. Jakarta: PT Gramedia Pustaka Utama.

Anthony, R. 1992. "Rahasia Membangun Kepercayaan Diri”. (terjemahan Rita Wiryadi). Jakarta: Binarupa Aksara.

Centi, P. J. 1995. “Mengapa Rendah Diri” . Yogyakarta : Kanisius.

Hakim, Thursam. 2005. “Mengatasi Rasa Tidak Percaya Diri”. Jakarta: Puspa Swara.

Lauster, P. 1997. "Test Kepribadian" (terjemahan Cecilia, G. Sumekto). Yokyakarta. Kanisius.

Santrock, John W. 2003. Adolescence: Perkembangan Remaja. Jakarta: Erlangga

Susanti, Florentina Rika. 2008. Hubungan antara Kepercayaan Diri dengan Penyesuaian Sosial Siswa Kelas VIII SMP Santa Maria Fatima, dalam Jurnal Psiko-Edukasi, Mei.

Wulan, Mawar Kusuma. "Tak Banyak Diminati, Pustakawan Minder". Dipublikasikan Kamis, 26 Agustus $2010 \quad$ dalam http://edukasi.kompas.com/read/2010/08/26/22093536/Tak.Banyak.Diminati.Pustakawan.Minder

Walgito, Bimo. 2002. Pengantar Psikologi Umum. Yogyakarta: Andi Offset.

Instone, D. Major, B \& Bunker. 1993. Self Confidence and Social Influence strategies; An Organizational Simulation . Journal of Personality and Social Psychology. Vol. 44, No. I. 